\title{
Preparation, characterization and antimicrobial activity of chitosan microparticles with thyme essential oil
}

\author{
Danijela Pecarski ${ }^{1}$, Zorica Knežević-Jugović ${ }^{2}$, Suzana Dimitrijević-Branković ${ }^{2}$, Katarina Mihajilovski ${ }^{2}$, \\ Slobodan Janković ${ }^{3}$ \\ ${ }^{1}$ Sanitary and Medical School of Professional Studies "Visan", Belgrade, Serbia \\ ${ }^{2}$ University of Belgrade, Faculty of Technology and Metallurgy, Belgrade, Serbia \\ ${ }^{3}$ University of Kragujevac, Faculty of Medical Science, Kragujevac, Serbia
}

\begin{abstract}
Development of an available drug delivery system is of great interest considering the therapeutic effects of formulations with violate essential oils, especially assuming the fact that using essential oils as antimicrobial agents is a rather expanded in antimicrobial therapy nowadays. In this paper, the chitosan microparticles with encapsulated thyme essential oil were prepared in the emulsion by cross-linking method. The effect of thyme oil and glutaraldehyde initial concentrations on particle size, morphology, and particle size distribution was investigated. In addition, the influence of these parameters on the encapsulation of thyme oil in chitosan microparticles, concerning thyme oil loadings and encapsulation efficiency was also tested. The particles showed a spherical shape with an average diameter of $4.71 \pm 1.42$ to $13.65 \pm 4.34 \mu \mathrm{m}$, depending on the concentration of the essential oil and glutaraldehyde that were used. The diameter of microparticles appeared to increase with increasing the thyme essential oil concentration, and decreased with the increase of glutaraldehyde concentration. It was shown that the concentration of glutaraldehyde did not affect the degree of encapsulation, but the increase in the initial concentration of thyme oil increased the degree of encapsulation of this essential oil in chitosan microparticles. All particles containing thyme essential oil, as well as essential oil of thyme itself showed significant antimicrobial activity against Staphylococcus aureus ATCC 25923, Esherichia coli ATCC 25922, Candida albicans ATCC 24433 and Enterococcus faecalis ATCC 25929. This study showed a great potential of the use of thyme essential oil as an antimicrobial agent, especially when encapsulated in a drug delivery system with controlled release of the active antimicrobial component.
\end{abstract}

Keywords: chitosan, thyme, antimicrobial activity, essential oil, microparticles.

Polymers

SCIENTIFIC PAPER

UDC

582.292.4:547.913:615.28:544.23

Hem. Ind. 68 (6) 721-729 (2014)

doi: 10.2298/HEMIND140415048P

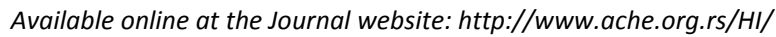

The main purpose of the drug therapy of any disease is to maintain the desired therapeutic concentration of the drug for the entire duration of the treatment. Essential oils are secondary metabolites of plants with very complex structures based on the terpenoid substances, which show great antibacterial activity, especially from the plants belonging to Lamiaceae family, documented by number of studies $[1,2]$. Thyme essential oil shows very strong antimicrobial effect on large number of bacteria and fungi and it is very interesting in antimicrobial therapy in the era of antimicrobial resistance [3]. Essential oils, thyme oil as well, are volatile compounds which easily evaporate, and decompose during drug and cosmetics formulation, and direct exposure to heat, pressure, oxygen or light [4]. Their encapsulation inside the particles is very

Correspondence: D. Pecarski, Sanitary and Medical School of Professional Studies "Visan", Tošin bunar 7/a, Belgrade, Serbia.

E-mail: pecarski@eunet.rs

Paper received: 15 April, 2014

Paper accepted: 6 June, 2014 important to protect bioactive components that are consisted in essential oils, from the direct contact of the external factors that can change their biochemical properties. Encapsulation is, thus, the best way to retain functional properties of the essential oil and to reach promising therapeutic effect, that essential oils show in in vitro testing [5].

Chitosan is a biodegradable, biocompatible, mucoadhesive and nontoxic natural polymer and has great potential for pharmaceutical application as drug and therapeutic enzyme carriers $[6,7]$. The physical and chemical properties of chitosan make this polymer also a rather attractive for encapsulation of thyme essential oil. It is a natural linear polysaccharide, obtained by alkaline deacetylation of chitin, which is a component of the protective cuticles of crabs, shrimps and other crustaceans and fungal mycelia [8]. Chitosan is soluble in acid conditions, but it has poor solubility above $\mathrm{pH}$ 6.5. It is structurally a linear polysaccharide composed of repeating units of B-(1-4)-2-amino-2-deoxy-D-glucopyranose (D-glucosamine), and has free amino groups on its polymeric chains. These amino groups protonate 
and give chitosan its cationic character that determines its main properties: controlled drug release for anionic substances, mucoadhesive properties, in situ gelling properties, etc [9]. Based on the antimicrobial properties of chitosan itself [9], this would be a great choice for the preparation of particles with incorporated antimicrobial essential oils such as thyme, in order to design a potent antimicrobial formulation for therapeutic use. Biodegradable, nontoxic, mucoadhesive and biocompatible properties make chitosan a promising biopolymer for the preparation of microparticles by different techniques: cross-linking with different crosslinking agents (glytaraldehyde, formaldehyde or genipin), spray drying, ionotropic gelation, simple and complex coacervation [11]. Among all these techniques, the emulsion cross-linking method would be the method of choice for the preparation of chitosan particles with essential oil of thyme, because some other methods involve temperature, high pressure, etc. The cross-linking method is based on the reaction of the amino group of chitosan and the aldehyde group of the cross-linking agent $[12,13]$.

The primary aim of this study was to explore the potential of chitosan as a carrier for encapsulation of thyme essential oil. For this purpose, the effects of thyme and glutaraldehyde concentrations on particle size and size distribution, morphology and encapsulation efficiency were investigated. The second objective was to test the in vitro antimicrobial activity of optimized chitosan microparticles and thyme oil itself, as well as to control empty chitosan microparticles and to compare results. Overall, the main objective of this study was to design an effective biodegradable antimicrobial drug delivery system which would be very useful in antimicrobial therapy.

\section{MATERIALS AND METHODS}

\section{Materials}

Medium molecular weight chitosan (75-85\% degree of deacetylation, CAS \#9012-76-4), were purchased from Sigma-Aldrich (St. Louis, MO, USA). Acetic acid, lactic acid, Tween 80 (polysorbate 80 ) and glutaraldehyde were purchased from Merck Chemicals Co. (Darmstadt, Germany). Thyme essential oil was purchased from Sanoflore (France).

\section{Microorganisms}

For the purpose of in vitro testing of antimicrobial activity of thyme essential oil and chitosan particles with thyme, the following standardized bacterial and fungi cultures were used (ATCC - American Type Culture Collection): Staphylococcus aureus ATCC 25923, Esherichia coli ATCC 25922, Candida albicans ATCC 24433 and Enterococcus faecalis ATCC 29212. These cultures of microorganisms were propagate in Tripton soya broth and agar and used in antimicrobial assays as freshly prepared overnight broth cultures.

\section{Gas chromatography with mass spectrometry (GC-MS)}

Gas-chromatographic analysis of essential oils was conducted with Hewlett Packard 5973-689 GC-MS system in El mode on $70 \mathrm{eV}$ with spectrometric detection of masses. Initial temperature of capillary column HP $5 \mathrm{MS}(30 \mathrm{~mm} \times 0.25 \mathrm{~mm}$; film thickness $0.25 \mu \mathrm{m}$ ) was 60 ${ }^{\circ} \mathrm{C}$. Using the heating speed of $3{ }^{\circ} \mathrm{C} / \mathrm{min}$, it was heated to $280{ }^{\circ} \mathrm{C}$. Helium was gas carrier for this purpose, and it had the flow of $1 \mathrm{ml} / \mathrm{min}$. The amount of $1 \mu \mathrm{l}$ of each investigated sample was injected in GC column in proportion of 1:10.

Identification of components was based on calculated retention indexes $(R I)[14]$ and mass spectra compared with standard substances and/or with NIS/NBS Wiley library of mass spectra, including literature data or data from free database (http//www. flavornet.org/iowtv.pherobase.com) [15]. Experimental values of retention indexes are defined using calibrated automated mass spectral deconvolution and identification system software (AMDIS ver. 2.1, DTRA/ /NIST, 2002). Results are compared with retention indexes from literature data and via internet available database.

\section{Preparation of chitosan microparticles}

Chitosan microparticles with encapsulated essential oil were obtained by the emulsion cross-linking method. The two series of the particles were made: one with varied concentration of essential oils $(3,6,12$ and $15 \mu \mathrm{l} / \mathrm{ml}$ ) and the other with varied concentration of the cross-linking agent glutaraldehyde $(2,3,5$ and $8 \%)$.

$10 \mathrm{ml}$ of $1 \%$ of chitosan solution in $1.65 \%$ lactic acid is added to $50 \mathrm{ml}$ of liquid paraffin solution with thyme essential oil and $2 \%$ Tween 80 , as a surfactant resulting in formulation of $\mathrm{w} / \mathrm{o}$ emulsion. The phases were mixed on the magnetic stirrer (10 $\mathrm{min}$ at $8000 \mathrm{rpm}$ ), to become homogenous. After that glutaraldehyde, as a cross-linking agent, was added under condition of mixing $30 \mathrm{~min}$ at $10000 \mathrm{rpm}$ (Yellowline, DI 25 basic, Ica Works Inc., Wilmington, 8000-24000 rpm), and the microparticles were spontaneously formed. The resultant microparticles were collected by centrifugation (Sigma 2-16, rotor 12141, Germany), for $10 \mathrm{~min}$ at 4000 $\mathrm{rpm}$. The supernatant volume was separated and measured, as it will be later used in the calculation (to determine how much of thyme has not been incorporated into the microparticles). The remaining solid phase contained microparticles, and they were sequentially washed with $175 \mathrm{ml}$ of $1 \%$ Tween solution, then with $80 \mathrm{ml}$ of ethanol and finally with $75 \mathrm{ml}$ of distilled water. Ethanol had the role of removing any 
remaining polar compounds that were not encapsulated. The volume of the separated content is measured. The mass of the particles was measured on an analytical balance. The microparticles for microscopic imaging are stored in acetate buffer, $\mathrm{pH} 4.6$, in a regular container. They are poured into it, and the container is filled up to the marker with acetate buffer.

\section{Determination of thyme essential oil loading and encapsulation efficiency}

Thyme essential oil loading, TEOL $(\mathrm{mg} / \mathrm{g})$, was determined from the following equation:

$$
\text { TEOL }=\frac{\left[C_{0} V_{0}-\left(C_{1} V_{1}+C_{2} V_{2}\right)\right]}{w}
$$

where $C_{0}$ is the thyme oil (polyphenols) concentration of the initial solution $(\mathrm{mg} / \mathrm{ml}) ; V_{0}$ its volume $(\mathrm{ml}) ; C_{1}$ the thyme oil concentration in the supernatant $(\mathrm{mg} / \mathrm{ml}) ; V_{1}$ the volume of supernatant $(\mathrm{ml}) ; C_{2}$ the thyme oil concentration in washing solutions $(\mathrm{mg} / \mathrm{ml})$ and $V_{2}$ their volumes $(\mathrm{ml}) ; w$ the weight of dry chitosan microparticles (g).

The efficiency of thyme encapsulation (EE, \%) was measured as also the amount of thyme (polyphenols) encapsulated in microspheres $\left(m_{\mathrm{e}}\right)$, divided by the total amount of thyme (total polyphenols, $m$ used for the preparation of microparticles, as shown in Eq. (2):

$$
E E \%=\frac{m_{e}}{m}
$$

The most reliable method for the determination of total polyphenols is the Folin-Ciocalteau (FC) method [16]. Reaction of polyphenols and FC reagent (mixture phosphor-wolfram and phosphor-molybdenum acids) in mild alkaline conditions leads to the formation of a relatively stable blue colored complex, which can be spectrophotometrically determined at $765 \mathrm{~nm}$ using UV-Vis spectrophotometer (Ultrospec 3300 pro, Amerischam Bioscience).

\section{Microparticles characterization}

Once made, microparticles are photographed and measured. Electronica microscope is used (Carl Zeiss $\mathrm{GmbH}$, Wien). Suspension of microparticles is carefully placed on watch glass, and placed under a 200 times magnification lens, field of view is found, and the sample is photographed. For making the images, we used the program Axi Vision 4.6.

\section{Methods of determination of antimicrobial activity}

Agar well diffusion method was employed for the determination of antimicrobial activity of the thyme essential oil, as well as for chitosan microparticles. Tubules with diameter of $6 \mathrm{~mm}$ were placed on Petri plates with prepared sterile TSA (tryptone soya agar,
Torlak, Serbia). After overlaying with soft TSA $(0.60 \%$ of agar-agar) inoculated with the indicator microorganism, the tubules were removed and the obtained wells were filled with $20 \mu \mathrm{l}$ of thyme essential oil. Plates are incubated at $37{ }^{\circ} \mathrm{C}$ during $24 \mathrm{~h}$. The antimicrobial activity of thyme, lactic acid $(20 \mu \mathrm{l})$, and of combined thyme oil and lactic acid (the compound included $50 \mathrm{ppm}$ of lactic acid for $20 \mu \mathrm{l}$ of essential oil) was investigated in order to determine their synergistic effect. Antibiogram tablets of clindamycin and nystatine $(30 \mathrm{mg}$ ) were used as a positive control for the comparation of the antibacterial activity of essential oils.

Series of solutions of chitosan microparticles were made with various concentrations of essential thyme oil $(0.3,0.6,1.2$ and $1.5 \%)$ and have been kept in $0.5 \mathrm{M}$ acetate buffer, $\mathrm{pH}$ 4.8. These solutions were prepared in the following manner: $0.31 \mathrm{~g}$ chitosan microparticles of various concentrations of thyme essential oil and $610 \mathrm{ml}$ acetate buffer were mixed. For the antimicrobial analyses, $20 \mu \mathrm{l}$ of dissolved chitosan microparticles were added in the agar wells, prepared as mentioned above.

Antimicrobial activity of thyme itself and chitosan micropaticles with encapsulated thyme oil are expressed by the inhibition zones which are measured and expressed in $\mathrm{mm}$.

\section{Statistical analysis}

Data were summarized as mean \pm standard deviation $(S D)$. Data were analyzed by descriptive statistic using one way ANOVA test. Turkey test was used for comparing average values $(p>0.01)$.

\section{RESULTS AND DISCUSSION}

\section{Chemical composition of thyme essential oil}

Properties of essential oils can be changed, depending on their origin and composition. Thus, the chemical composition of thyme essential oil used in the current research has been investigated and the results are shown in Figures 1 and 2.

According to the results of the chemical analysis of thyme essential oil, 25 compounds were identified, which represented $94.53 \%$ of the oil content. It can be noted that the highest percentage of compounds includes three classes: monoterpene hydrocarbons, aromatic hydrocarbons and oxidized monoterpenes. Other groups of compounds are present in less than $1 \%$ (Figs. 1 and 2). More than half of total compounds of thyme essential oil include 6 dominant compounds. Among them, the most dominant is the oxidized monoterpene thymol (36.12\%) and the monoterpene hydrocarbon $p$-cymene $(21.15 \%)$. Other dominant components of this essential oil are the following: $\gamma$-terpinene 


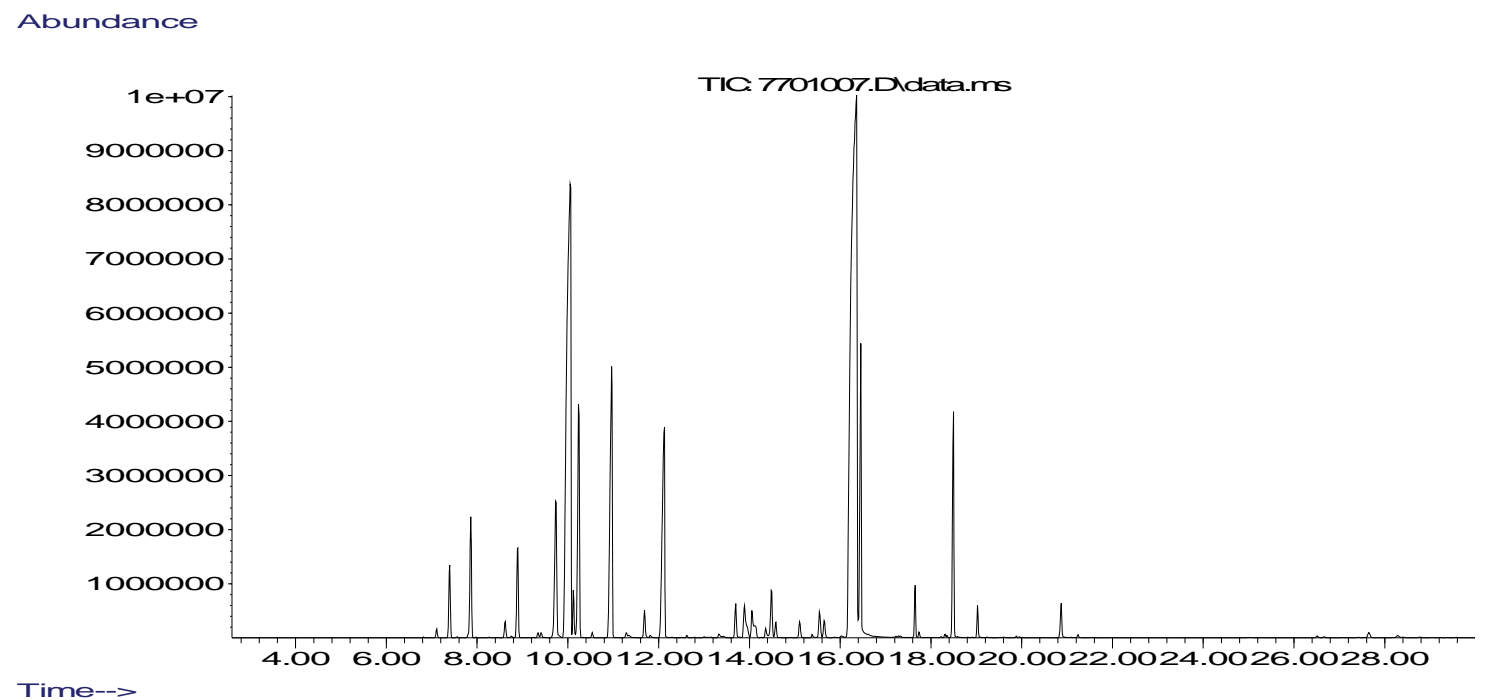

Figure 1. GC-MS chromatogram of thyme essential oil.
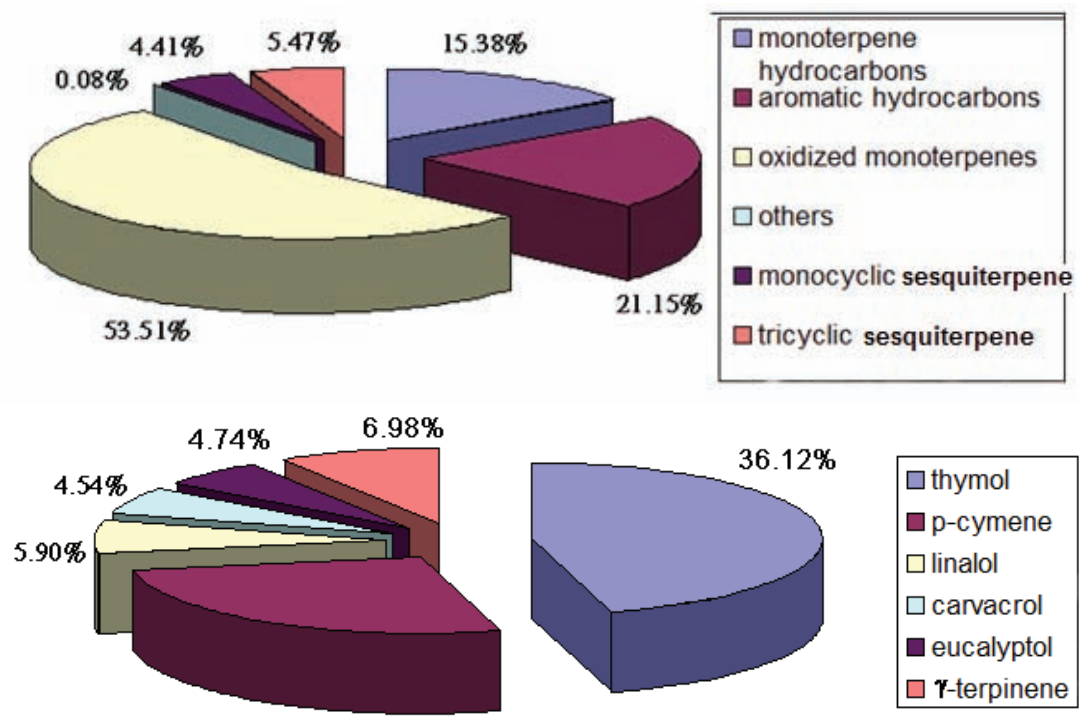

$21.15 \%$

Figure 2. The basic compound classes in the thyme essential oil.

(6.98\%), linalol (5.90\%), carvacrol $(4.54 \%)$ and eucalyptol (4.74\%) (Figure 2).

These results are in accordance with previous published data about chemical composition of thyme essential oil [17]. The main components of essential oils determine the biological and pharmacological features of the oil itself. Therefore, the chemical composition of a certain essential oil will be important for its antibacterial activity.

\section{Antimicrobial activity of thyme essential oil and chitosan microparticles}

The in vitro antimicrobial activity of thyme oil and chitosan microparticles against aforementioned microorganisms, and their potential activities were assessed qualitatively and quantitatively by the presence or abs- ence of inhibition zones, and the zone diameters were expressed in $\mathrm{mm}$. According to the results represented in Table 1 and Fig. 3, thyme essential oil, as well as chitosan microparticles containing this oil, showed significant antibacterial and antifungal activity against all tested indicator strains. With increasing the initial concentration of essential oil from 0.3 to $1.5 \%$, the inhibition zones increased from 4 to $6 \mathrm{~mm}$ against $S$. aureus. The same trend was observed for the inhibition zones against tested microorganisms: E. faecalis, C. albicans and $E$. coli (Table 1). Hence regardless of the tested bacteria and fungi the increase of the concentration of encapsulated essential oil in chitosan microparticles led to an increase of the inhibition zones.

Concerning Gram-positive bacteria, S. aureus (12 $\mathrm{mm}$ ) was more sensitive than $E$. faecalis $(8 \mathrm{~mm})$ to 
Table 1. Antimicrobial activity (Inhibition zone, $\mathrm{mm}$ ) of chitosan microparticles containing different concentrations of thyme essential oil and chitosan itsef (data for $0.0 \%$ ) against used bacteria and fungi

\begin{tabular}{|c|c|c|c|c|}
\hline \multirow{2}{*}{$\begin{array}{l}\text { Initial concentration of thyme essential } \\
\text { oil, vol.\% }\end{array}$} & \multicolumn{4}{|c|}{ Bacterium } \\
\hline & S. aureus & E. coli & C. albicans & E. faecalis \\
\hline 0.0 & 2.5 & 2.0 & 1.5 & 2.0 \\
\hline 0.3 & 4.0 & 2.5 & 2.5 & 2.5 \\
\hline 0.6 & 4.5 & 3.5 & 3.0 & 2.5 \\
\hline 1.2 & 5.0 & 4.5 & 5.0 & 3.0 \\
\hline 1.5 & 6.0 & 5.0 & 5.0 & 3.5 \\
\hline
\end{tabular}
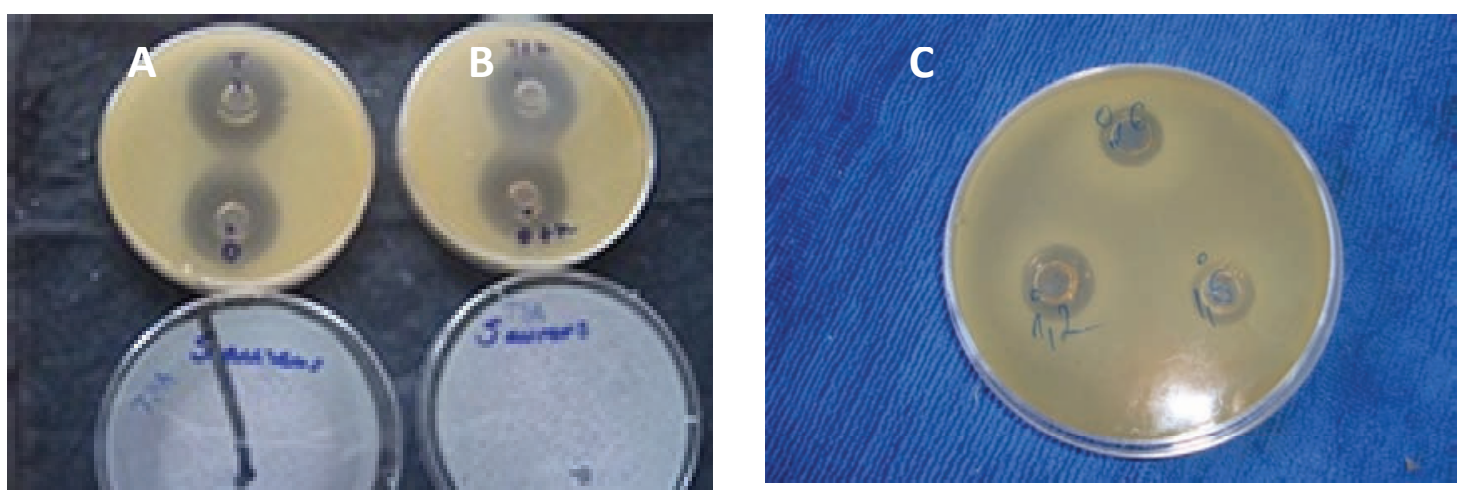

Figure 3. Antimicrobial activity of thyme and oregano essential oils and their combination with lactic acid against S. aureus, and of chitosan microparticles containing thyme essential oil against S. aureus. A) Inhibition zones of thyme and oregano essential oils; B) inhibition zones of combined thyme oil and lactic acid and oregano oil and lactic acid; C) inhibition zones of chitosan microparticles containing $0.6,1.2$ and $1.5 \%$ thyme essential oil.

thyme essential oil. Slightly less sensitive was Gramnegative bacteria $E$. coli $(0.8 \mathrm{~mm})$. The thyme oil also showed antifungal activity against $C$. albicans $(2 \mathrm{~mm})$. Low sensitivity of Gram-negative bacteria to essential oils can be the consequence of the construction of their cell wall which includes an external membrane around the peptidoglycan layer, which also inhibits diffusion of hydrophobic components through their lipopolysaccharide layer [18].

The antibacterial activity of essential oils with high content of thymol and carvacrol, such as thyme essential oil (thymol-36.12\% and $4.54 \%$ carvacrol), is very well documented [19].

Also, chitosan microparticles containing thyme oil showed significant antimicrobial activity, as well as non-loaded chitosan microparticles, which was expected due to the known antimicrobial effect of chitosan itself [20].

\section{Encapsulation of thyme essential oil in chitosan microparticles}

Chitosan microparticles with different concentrations of thyme essential oil

In this study, thyme essential oil has been encapsulated in chitosan microparticles by the oil-in-water (o/w) emulsion cross-linking method. The effects of initial thyme essential oil concentration in the range from 0.3 to 1.5 vol.\% on thyme essential oil loading and encapsulation efficiency were first investigated. The results are presented in Fig. 4.

The increase of the initial thyme concentration affected significantly its loading. Thyme essential oil loading increased rapidly with increasing concentration of thyme oil in the initial solution and then reached a maximum value of $58.85 \pm 1.32 \mathrm{mg} / 100 \mathrm{mg}$ of microparticles. It seemed that the maximum loading for chitosan microparticles was not reached in this experiment. The encapsulation efficiency appeared to slightly increase with the thyme concentration, being in the range from $77.89 \pm 4.0$ to $85.56 \pm 7.19 \%$, for thyme concentration of 0.3 and 1.5 vol.\%, respectively. This result is in accordance with previous published data [21,22].

Chitosan microparticles with different concentrations of glutaraldehyde

In order to study the effect of glutaraldehyde concentration on particle size and encapsulation efficiency, thyme oil concentration was fixed at 1.2 or $1.5 \%$, while the glutaraldehyde concentration was varied in the range from 2 to $8 \%$. The results are presented in Table 2 and Fig. 5. Optical microscopy images of the microcapsules are shown in Fig. 6.

According to the results presented in Fig. 5, the concentration of glutaraldehyde did not significantlly affect the degree of thyme oil encapsulation. However, an optimal glutaraldehyde concentration is required for 


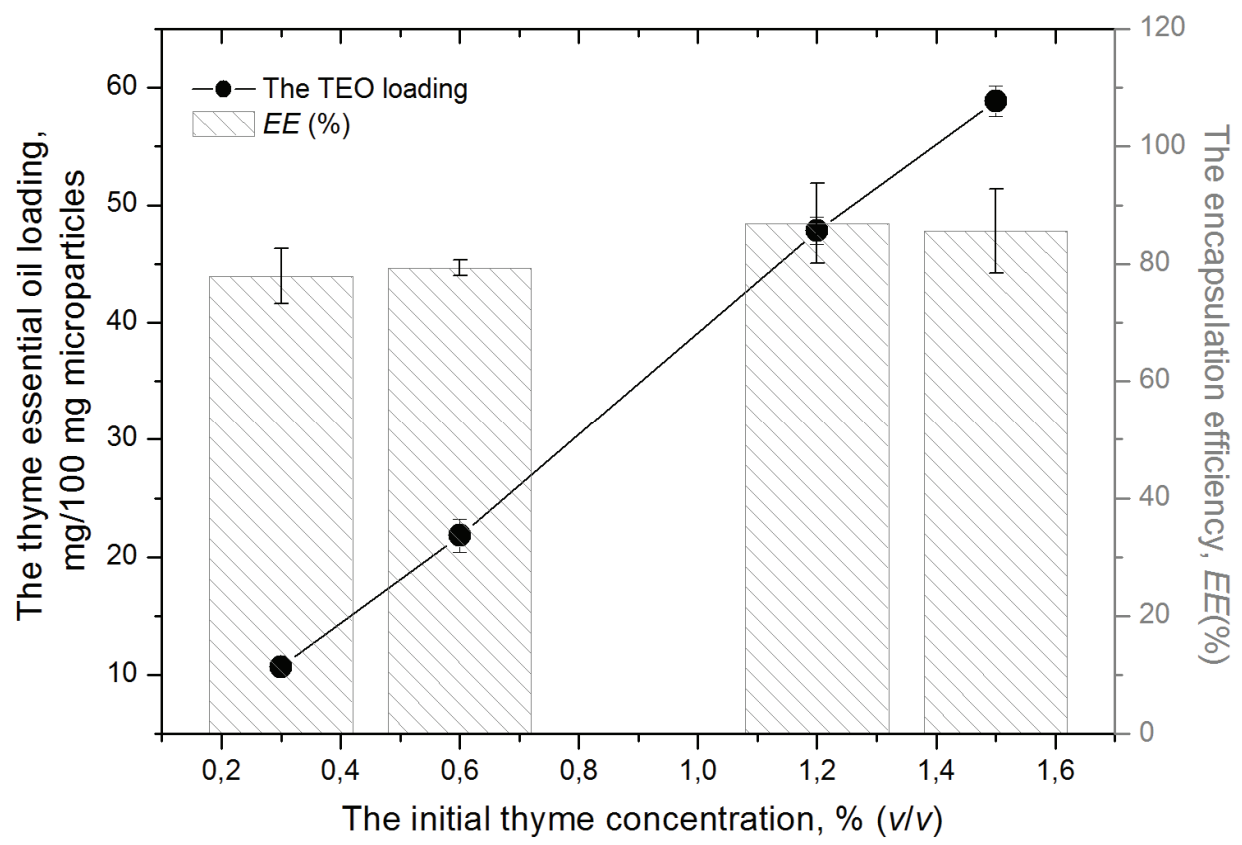

Figure 4. The effect of thyme essential oil concentration on the thyme oil loading and encapsulation efficiency.

Table 2. The effects of glutaraldehyde concentration on the thyme essential oil loading, TEOL, and encapsulation efficiency (EE, \%) as well as on particle diameters with statistical analysis of chitosan microparticles diameter; TEOL - thyme essential oil loading; EE - encapsulation efficiency; ADS - average diameter size; STD - standard deviation; SE - standard error

\begin{tabular}{lccccc}
\hline Initial glutaraldehyde concentration, \% & $T E O L, \mathrm{mg} / 100 \mathrm{mg}$ & $E E, \%$ & $A D S, \mu \mathrm{m}$ & $S T D$ & $S E$ \\
\hline 2 & 58.51 & 85.07 & 12.85 & 3.61935 & 0.80931 \\
3 & 59.10 & 85.94 & 13.65 & 4.34231 & 0.97097 \\
5 & 57.04 & 82.94 & 7.192 & 3.16752 & 0.70828 \\
8 & 58.52 & 85.09 & 4.710 & 1.41743 & 0.31695 \\
\hline
\end{tabular}

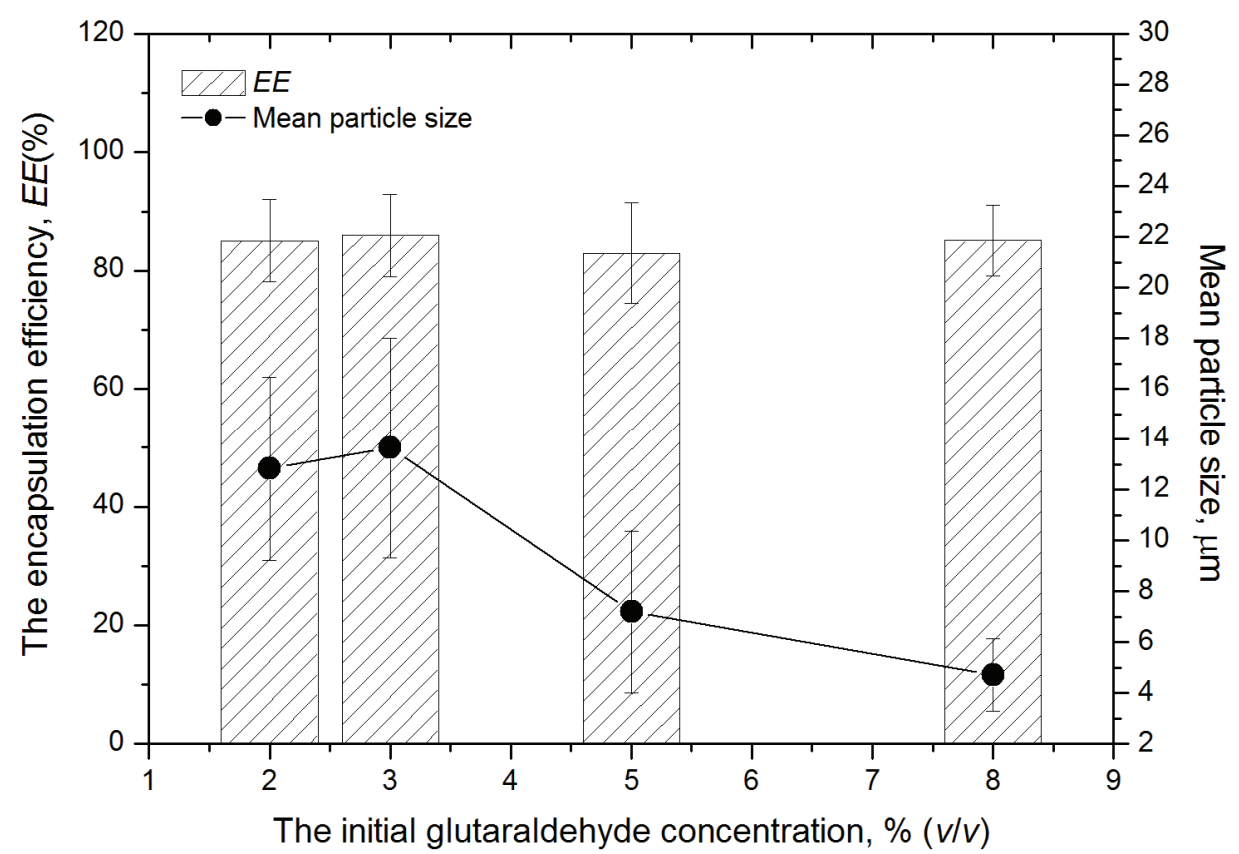

Figure 5. The effect of glutaraldehyde concentration on the thyme oil encapsulation efficiency (EE, \%) and particle diameters. 
chitosan microparticles formation regarding their shape, size and size distribution (Fig. 6). Namely, microparticles were spherical in shape with smooth surfaces. Except for few cases, the droplets of thyme oil appeared to be individually encapsulated as spherical particles with size distribution consistent with a microparticle size and one can notice also the absence of agglomerates.

The microspheres had a mean particle size in the range from $4.71 \pm 1.42$ to $13.65 \pm 4.34 \mu \mathrm{m}$. Such particles were considered to be of the appropriate size suitable for several administrations. There was no significant difference in the particles size between microparticles with 2 and 3\% glytaraldehyde used as cross-linking agent, neither in microparticles with 5 and $8 \%$ glytaraldehyde used. However, significant differences in particle size $(p<0.01)$ were found for particles with $2 \%$ glutaraldehyde compared to particles with 5 and $8 \%$ microparticles with encapsulated thyme oil on four tested microorganisms: Staphylococcus aureus, Escherichia coli, Candida albicans and Enterococcus faecalis. Gram-positive bacteria were more sensitive to microparticles with thyme essential oil, and thyme oil itself, than gram-negative bacteria.

The results revealed that essential oil concentration in microparticles had the most important influence on the diameter of the inhibition zone against tested microorganisms, as well on the diameter of chitosan microparticles that were made. The increase of the concentration of thyme essential oil in the chitosan microparticles induced an increase in the diameter of the inhibition zones of the tested microorganisms. On the other hand, the diameter of chitosan micropaticles decreased with increasing the concentration of the cross-linking agent glutaraldehyde, that was used for preparing microparticles. It is important to emphasize
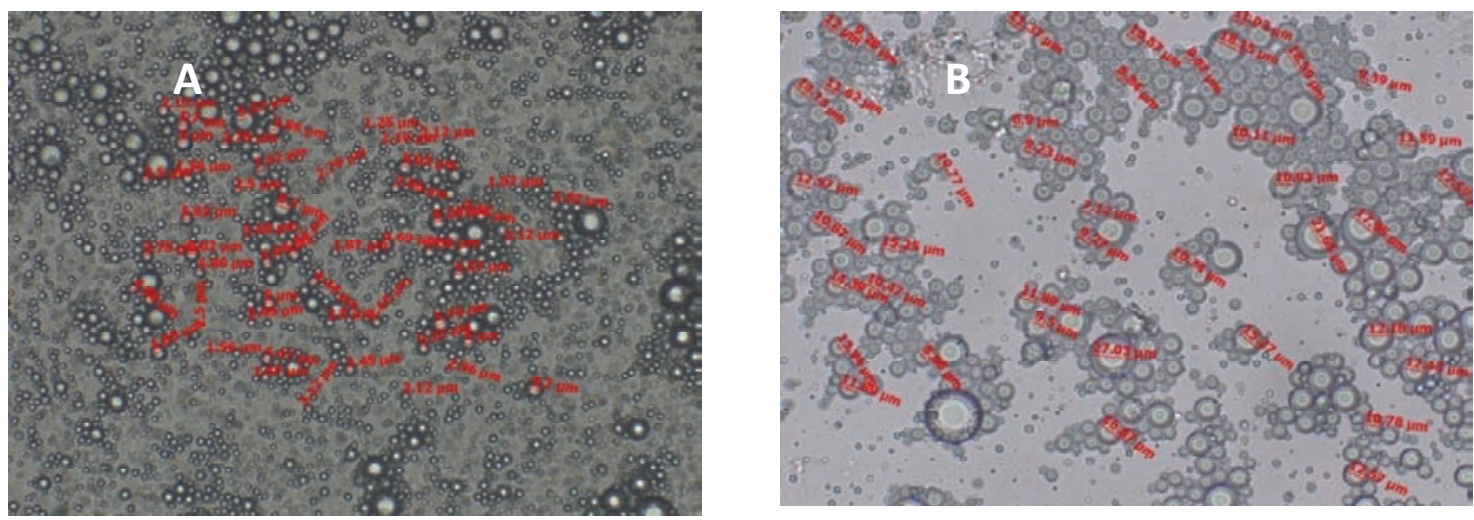

Figure 6. Electron microscopy of chitosan microparticles with encapsulated thyme essential oil and containing glutaraldehyde as the crosslinking agent. A) microparticles with encapsulated $1.5 \%$ thyme essential oil and 8\% glutaraldehyde (average size of microspheres was $4.71 \mu \mathrm{m}$ ); B) microparticles with encapsulated 1.5\% thyme oil and 3\% glutaraldehyde (average diameter of the particles is $13.64 \mu \mathrm{m})$.

glytaraldehyde used as cross-linking agent, as well as for microparticles size with $3 \%$ glutaraldehyde compared with size of particles with 5 and $8 \%$ glutaraldehyde.

It appeared that the diameter of microparticles decreased with the increase of glutaraldehyde concentration. These results were similar to these reported in other studies [23-25], although there are not many reports about essential oils and their constituents being encapsulated.

In the present study, it was shown that the employed emulsion method was suitable for the preparation of chitosan microparticles for the purpose of thyme oil encapsulation.

\section{CONCLUSIONS}

The present work aimed to study the antimicrobial activity of thyme essential oil, as well as chitosan that this research has not yet been reported in literature. Also the results of the determination of the influence of initial concentration of thyme essential oil on its encapsulation efficiency showed that the increase in the initial concentration of thyme increased its degree of encapsulation in chitosan microparticles. In the same experiment it was shown that the concentration of glutaraldehyde did not affect the degree of encapsulation.

These results of the study showed the potent antimicrobial effect of chitosan microparticles with thyme essential oil for future application in antimicrobial therapy.

\section{REFERENCES}

[1] N.C.C. Silva, A. Fernandes Júnior, Biological properties of medicinal plants: a review of their antimicrobial activity, J. Venom. Anim.Tox. Incl. Trop. Dis. 16 (2010) 402-413. 
[2] M. Marino, C. Bersani, G. Comi, Impedance measurements to study the antimicrobial activity of essential oils from Lamiacea and Compositae, Int. J. Food Microbiol. 67 (2001) 187-195.

[3] S. Cosentino, C.I. G Tuberoso, B. Pisano, M. Satta, V. Mascia, E. Arzedi, In vitro antimicrobial activity and chemical composition of Sardinian Thymus essential oils, Lett. Appl. Microbiol., 29 (1999) 130-135.

[4] F. Bakkali, S. Averbeck, D. Averbeck, M. Idaomar, Biological effects of essential oils - A review, Food Chem. Toxicol. 46 (2008) 446-475.

[5] A. Sunil, N. Nadagouda, T. Mallikarjuna, M. Aminabhavi, Recent advances on chitosan-based micro- and nanoparticles in drug delivery, J. Control. Release 100 (2004) 5-28.

[6] A. Smelcerović, Z. Knežević-Jugović, Ž. Petronijević, Microbial polysaccharides and their derivatives as current and prospective pharmaceuticals, Curr. Pharm. Des. 14 (2008) 3168-3195.

[7] M.G. Žuža, B.M. Obradović, Z.D. Knežević-Jugović, Hydrolysis of Penicillin G by Penicillin G Acylase Immobilized on Chitosan Microbeads in Different Reactor Systems, Chem. Eng. Technol. 34 (2011) 1706-1714.

[8] V.R. Sinha, A.K. Singla, S. Wadhawan, R. Kaushik, R. Kumria, K. Bansal, S. Dhawan, Chitosan microspheres as a potential carrier for drugs, Int. J. Pharm. 274 (2004) 1-33 .

[9] S.G. Kumbar, A.R. Kulkarni, T.M. Aminabhavi, Crosslinked chitosan microspheres for encapsulation of diclofenac sodium: effect of cross-linking agent, J. Microencapsulation 19 (2002) 173-180.

[10] F. Chellat, M. Tabrizian, S. Dumitriu, E. Chornet, C.H. Rivard, L Yahia, Study of biodegradation behavior of chitosan-xanthan microspheres in simulated physiological media, J. Biomed. Mater. Res. 53 (2000) 592-599.

[11] A.A. Al-Helw, A.A. Al-Angary, G.M. Mahrous, M.M. Al-Dardari, Preparation and evaluation of sustained release cross-linked chitosan microspheres containing phenobarbitone, J. Microencapsulation 15 (1998) 373-382 .

[12] J. Meng, T.F. Sturgis, B.C. Youan, Engineering Tenofovir Loaded Chitosan Nanoparticles, Eur. J. Pharm. Sci. 44 (2011) 57-67.

[13] A. Groboillot, C. Champagne, G. Darling, D. Poncelet, R. Neufeld, Membrane formation by interfacial cross-linking of chitosan for microencapsulation of Lactococcus lactis, Biotechnol. Bioeng. 10 (1993) 1157-1163.

[14] H. Van den Dool, D.P. Kratz, A Generalisation of the Retention Index System Including Linear Temeprature
Programmed Gas-Liquid Partition Chromatography, J. Chromatogr. 11 (1963) 463-471.

[15] R.P. Adams, Identification of Essential Oil Component by Gas Chromatography/Quadrupole Mass Spectrometry, Allured Publishing Corporation, Carol Stream, IL ,2007.

[16] A. Blainski, G.C. Lopes, J. C. Palazzo de Mello, Application and Analysis of the Folin Ciocalteu Method for the Determination of the Total Phenolic Content from Limonium brasiliense L., Molecules 18 (2013) 6852$-6865$

[17] N. Chorianopoulos, E. Kalpoutzakis, N. Aligiannis, S. Mitaku, G.J. Nychas, S.A. Haroutounian, Essential Oils of Satureja, Origanum and Thymus Species: Chemical Composition and Antibacterial Activities Against Food borne Pathogens, J. Agric. Food Chem. 52 (2004) 8261-8267.

[18] I.M. Helander, H.L. Alakomi, K. Latva-Kala, T. Mattila-Sandholm, I Pol, E.J. Smid, L.G.M. Gorris, A. Von Wright, Characterization of the action of selected essential oil compnents on Gram-negative bacteria, J. Agric. Food Chem. 46 (1998) 3590-3595.

[19] L.P. Roldan, G.J. Diaz, J.M. Duringer, Composition and antibacterial activity of essential oils obtained from plants of the Lamiaceae family against pathogenic and beneficial bacteria, Revista Colombiana de Ciencias Pecuarias 23 (2010) 451-461.

[20] L.-Y. Zheng, J.-F. Zhu, Study on antimicrobal activity of chitosan with differnt molecular weights, Carbohydr. Polym. 54 (2003) 527-530.

[21] W.C. Hsieh, C.P. Chang, Y.L. Gao, Controlled release properties of chitosan encapsulated volatile citronella oil microcapsules by thermal treatments, Colloids Surfaces, B 53 (2006) 209-214.

[22] C. Anchisi, M.C. Meloni, A.M. Maccioni, Chitosan beads loaded with essential oils in cosmetic formulations, J. Cosmet. Sci. 57 (2006) 205-214.

[23] Y. Pranoto, S.K. Rakshit, V.M.Salokhe, Enhancing antimicrobial activity of chitosan films by incorporating garlic oil, potassium sorbate and nisin, LWT-Food Sci. Technol. 38 (2005) 859-865.

[24] S.F. Hosseini, M. Zandi, Two-step method for encapsulation of oregano essential oil in chitosan nanoparticles: Preparation, characterization and in vitrorelease study, Carbohydr. Polym. 95 (2013) 50-56.

[25] W. Lyeverton, C. Ribeiro, I.T.F. Macedo, J.M. Leite dos Santos, Activity of chitosan-encapsulated Eucalyptus staigeriana essential oil on Haemonchus contortus, Exp. Parasitol. 135 (2013) 24-29. 


\title{
IZVOD
}

\section{IZRADA, KARAKTERIZACIJA I ANTIMIKROBNA AKTIVNOST HITOZANSKIH MIKROČESTICA SA ETARSKIM ULJEM TIMIJANA}

\author{
Danijela Pecarski ${ }^{1}$, Zorica Knežević-Jugović ${ }^{2}$, Suzana Dimitrijević-Branković ${ }^{2}$, Katarina Mihajilovski ${ }^{2}$, Slobodan Janković ${ }^{3}$ \\ ${ }^{1}$ Visoka Zdravstveno-Sanitarna škola "Visan", Tošinbunar 7/a, Beograd \\ ${ }^{2}$ Tehnološko-metalurški fakultet, Univerzitet u Beogradu, Karnegijeva 4, Beograd \\ ${ }^{3}$ Medicinski fakultet, Univerzitet u Kragujevcu, Svetozara Markovića 69, Kragujevac
}

(Naučni rad)

Etarska ulja kao antimikrobni agensi su sve više u upoterbi u antimikrobnoj terapiji, pa je i razvoj odgovarajućeg drug delivery sistema sa etarskim uljem od velikog terapijskog značaja. Inkapsulacija isparljivih etrskih ulja u odgovarajuće čestice je od velikog značaja da bi se žaštitile bioaktivne komponente, koje su sastavni deo etarskih ulja i koje su osetljive na direktno delovanje svetlosti, temperature i oksidacije jer ovi faktori menjaju njihove biohemijske osobine. Hitozan je biodegradibilan, biokompatibilan, mukoadhezivan i netoksičan prirodni polimer koji kao takav ima ogroman potencijal kao nosač aktivnih supstanci u farmaceutskim formulacijama. Hitozanske mikročestice sa inkapsuliranim etarskim uljem timijana su izrađene emulzionom metodom uz primenu urežavajućeg agensa. Varirane su koncentracije etarskog ulja timijana i glutaraldehida kao umreživača, i praćen je njhov uticaj na veličinu čestica, količinu inkapsuliranog timijana i efikasnost inkapsulacije. Hitozanske mikročestice su imale sferičan oblik sa prosečnim prečnikom koji je bio $u$ opsegu od $4.71 \pm 1.42$ to $13.65 \pm 4.34 \mu \mathrm{m}$, u zavisnosti od koncentracije etarskog ulja i glutaraldehida koji su korišćeni pri izradi čestica. Prečnik čestica, odnosno veličina čestica, je rasla sa povećanjem koncentracije etarskog ulja timijana i smanjivala se sa povećanjem koncentracije glutaraldehida. Pokazano je da koncentracija glutaraldehida nema uticaja na stepen inkapsulacije etarskog ulja timijana u hitozanske mikročestice, dok sa porastom koncentracije etarskog ulja timijana raste količina inkapsuliranog ulja i efikasnost inkapsulacije. Sve mikročestice, uključujući i samo etarsko ulje timijana, su pokazali značajnu antimikrobnu aktivnost protiv Staphylococcus aureus ATCC 25923, Esherichia coli ATCC 25922, Candida albicans ATCC 24433 i Enterococcus faecalis ATCC 25929. Ova studija je pokazala veliki antimikrobni potencijal etarskog ulja timijana inkorporiranog u hitozanske mikročestice kao odgovarajuću farmaceutsku formulaciju sa kontrolisanim oslobađanjem aktivne antimikrobne komponente.
Ključne reči: Hitozan • Timijan • Antimikrobna aktivnost • Patogeni • Mikročestice $\bullet$ Etarsko ulje 